Annex I. - Description of genetic entries for the second breeding cycle of Larix $\mathrm{x}$ marschlinsii in Québec, Can.

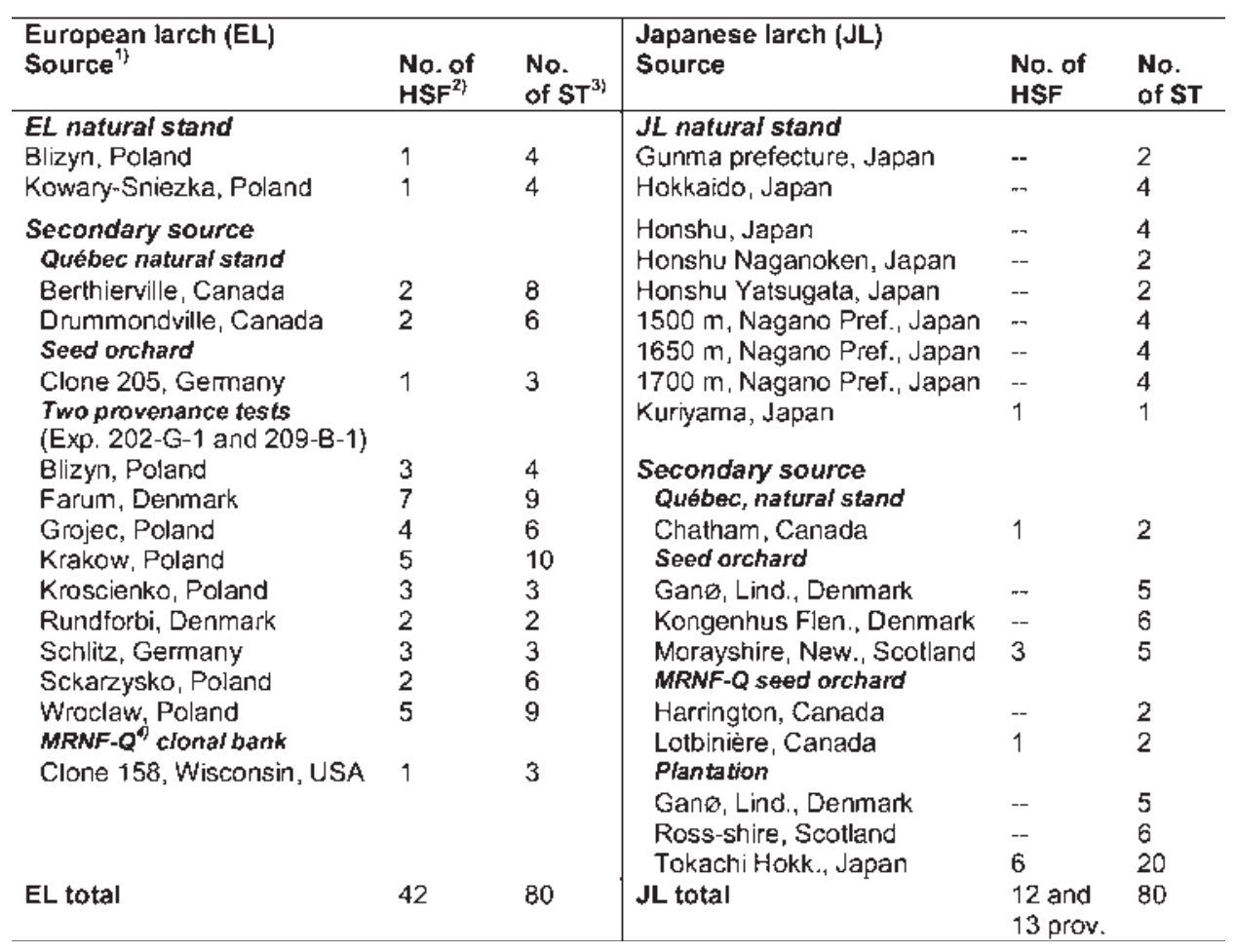

1) Origin of the mother trees.

2) $\mathrm{HSF}=$ half-sib family.

3) ST = selected tree. All ST are of MRNF-Québec provenance and progeny tests and seed orchards (4 JL elite-trees; based on 5 years results from two progeny tests).

4) MRNF-Q = ministère des Ressources naturelles et de la Faune du Québec.

\title{
Low Chloroplast DNA Diversity in Red Dogwood (Cornus sanguinea L.)
}

\author{
By H. LiesebaCH ${ }^{\left.1,{ }^{*}\right)}$ and B. GötZ ${ }^{2}$ \\ (Received 20 $0^{\text {th }}$ February 2008)
}

\begin{abstract}
The red dogwood Cornus sanguinea L. is a deciduous shrub of the temperate and Mediterranean zones. It is often used in landscape gardening for miscellaneous purposes.

Chloroplast DNA markers, the so-called cpDNA haplotypes, are a very potential marker type to characterise the large scale variation pattern within the natural range of a species.

\footnotetext{
1) Institute of Forest Genetics, Johann Heinrich von Thünen Institute (Federal Research Institute for Rural Areas, Forestry and Fisheries), Eberswalder Chaussee 3A, D-15377 Waldsieversdorf, Germany.

2) Forest Botanical Garden, University of Applied Sciences Eberswalde, Am Zainhammer 5, D-16225 Eberswalde, Germany.

*) Corresponding author: HeIKE LiesebaCh. Phone ++49(0)33433-157174, Fax ++49(0)33433-157199. E-Mail: heike.liesebach@vti.bund.de
}

In this study, a total of 86 populations and 673 individuals were sampled all over Europe. Eight different haplotypes were recognised by combinations of several PCR-RFLP patterns. They are divided into 3 groups of related types. There is no association between these 3 groups and their geographic occurrence within the tested material.

One haplotype strongly dominates in the whole distribution area. It takes nearly 90 percent whereas the remaining seven haplotypes together reach to approximately 10 percent. Besides the low number of haplotypes, the total genetic variation $\mathrm{H}_{\mathrm{T}}=0.15$ is much lower in Cornus sanguinea compared to other European tree and shrub species. Despite the low level of variation, several cases of introduced populations could be detected. Other haplotypes than the common type are found only in narrow areas. This result indicates that after the 


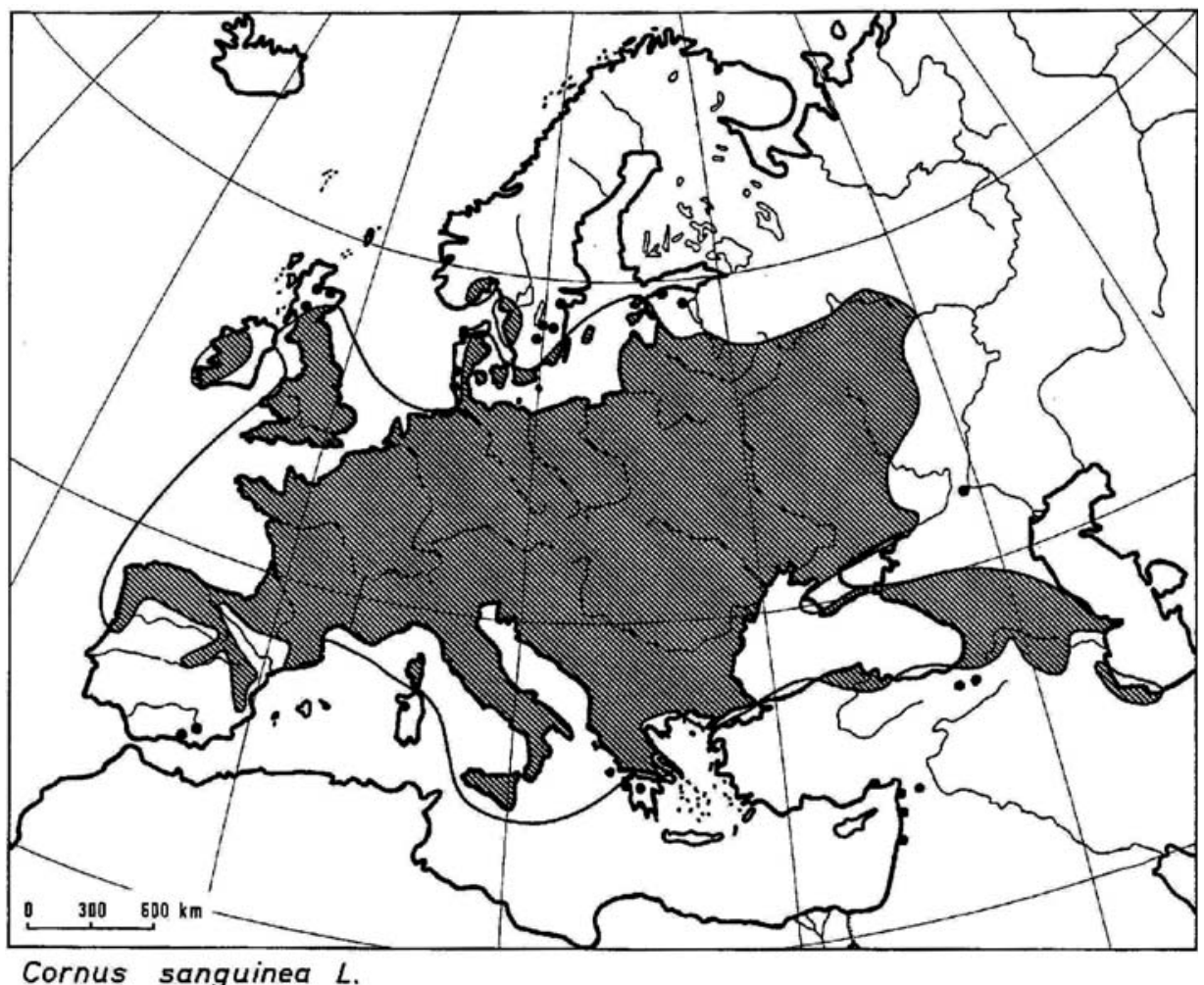

Figure 1. - Natural distribution area of Cornus sanguinea, adapted from MeUsel et al. (1978), HEGI (1975), ERHARDT at al. (2000) and ROLOFF and BÄrTELS (2006).

colonisation of the European continent only a very restricted gene flow could have taken place.

Key words: Cornus sanguinea L., red dogwood, genetic variation, chloroplast DNA, PCR-RFLP, haplotypes, gene flow, distribution area, introduced populations.

\section{Introduction}

The red dogwood (syn. bloodtwig dogwood), Cornus sanguinea L., is a deciduous shrub of the temperate and Mediterranean zones belonging to the Cornaceae family. Its wide distribution range covers nearly the complete European continent and the Caucasian region including the northern part of Iran. It is absent in Scandinavia with exception of the southernmost regions, in the north-eastern part of the British Islands, and the southern parts of the Iberian Peninsula and of Greece (Figure 1).

The red dogwood is a monoecious plant with a mostly outcrossing breeding system. Additionally it can propagate vegetatively by adventitious rooting. A partially clonal structure within a Cornus sanguinea population was detected by isozyme analysis (LeINEMANN et al., 2002). The species can adapt their reproductive behaviour to habitat conditions by changing the relative importance of reproduction by seed and vegetative clonal growth (KRÜSI and DeBUSSCHE, 1988). Its ecological significance is associated with the pollination of flowers by insects like beetles, flies, hover flies, wasps and bees and with the black-violet seeds that were eaten and dispersed by birds.

Red dogwood is often used in landscape gardening for miscellaneous purposes. It is of particular importance for soil rooting at slopes and for the cultivation of embankments.

In general, there is an increasing interest in cultivation of shrubs originating from local adapted populations. Reproduc- tive material from indigenous sources is recommended because of its better adaptability to local environmental conditions in comparison to material of the same species from far distant geographic regions and other climatic conditions.

Genetic markers with a geographic variation pattern in a respective species would be suitable to identify the geographic region of origin of plant material. Chloroplasts were maternally inherited in Angiosperms. The chloroplast DNA markers, the so-called cpDNA haplotypes, are a very potential marker type to characterize the large scale variation pattern within the natural range of a species, because these markers reflect the gene flow by seeds only and not by pollen.

Chloroplast DNA haplotypes were firstly applied for oak species in Europe in an extensive phylogeographic study (Dumolin-Lapegue et al., 1997a; Petit et al., 2002). Three large and additional three small groups of genetically related cpDNA haplotypes were identified. The three large lineages correspond to the three large refugia during ice age, the Iberian, Italian, and Balkan peninsulas and reflect the postglacial recolonisation routes throughout Europe.

Consensus primers derived from the tobacco chloroplast DNA sequence are suitable to amplify noncoding regions of chloroplast DNA. These noncoding regions have the potential to detect variation within species associated with geographic areas. The method was successfully adapted to several other European forest tree species, i.e. Fagus sylvatica (DEMESURE et al., 1996), Betula pendula (PalmÉ et al., 2004), Tilia cordata (FInESCHI et al., 2003), Fraxinus excelsior (HeUERTZ et al., 2004) and Populus nigra (CotTRELl et al., 2005). Within the "Cytofor" project (PETit et al., 2003) funded by the Commission of the European Communities, several shrub species were investigated, i.e. Corylus avellana (PAlme and Vendramin, 2002), Hedera sp. (GRIvet and Petit, 2002), Prunus spinosa (Mohanty et al., 
2002) and Ilex aquifolium (RENDELL and ENNos, 2003). Despite of some statistical significant phylogeographic structure detected for several species in 25 populations (PETIT et al., 2003) an attribution of samples to geographic regions needs much more populations for an inventory in the distribution area.

\section{Materials and Methods}

\section{Plant material}

Representative material was collected to cover large parts of the natural range of red dogwood in Europe with emphasis on Germany and south-eastern Europe (Tab. 1). A differentiation between the subspecies Cornus sanguinea ssp. sanguinea and occurring C. s. ssp. australis has not been made, because of less morphological differences and no observed crossing barrier (ROLOFF and BÄRTELS, 2006; MeYer et al., 2007). Natural stands with typical plant communities were selected as far as possible to harvest the material. Red dogwood understory in riverside forests seemed to be most convenient, even when cultivated forests were found at the riverside the dogwood understory was assumed not to be planted. Locations nearby settlements were avoided to exclude sampling of plants originating from cultured forms. Within Germany, the material was mainly collected from Federal states gene preservation populations.

The aim was to save leaves from 10 individuals at each site with a minimum distance of approximately 10 to 15 meters between the specimens to avoid sampling of vegetative ramets.

Table 1. - Geographic location of Cornus sanguinea populations sampled.

\begin{tabular}{|c|c|c|c|c|c|}
\hline $\begin{array}{l}\text { Pop } \\
\text { ID }\end{array}$ & Country & I ocation & $\begin{array}{c}\text { Longitude } \\
\mathrm{E}\end{array}$ & $\begin{array}{c}\text { I atitude } \\
N\end{array}$ & $\begin{array}{c}\text { Number } \\
\text { of } \\
\text { samples }\end{array}$ \\
\hline 1 & Albania & Tirana & $19^{\circ} 48^{\prime}$ & $41^{\circ} 18^{\prime}$ & 3 \\
\hline 2 & Austria & Ponigl/Graz & $15^{\circ} 27^{\prime}$ & $46^{\circ} 55^{\prime}$ & 10 \\
\hline 3 & Austria & Untere Lobau/Wien & $16^{\circ} 42^{\prime}$ & $48^{\circ} 09^{\prime}$ & 10 \\
\hline 4 & Austria & Nussbacts & $14^{\circ} 06^{\prime}$ & $48^{\circ} 00^{\top}$ & 9 \\
\hline 5 & Austria & Schlierbach/Au 1 & $14^{\circ} 06^{\prime}$ & $47^{\circ} 54$ & 4 \\
\hline 6 & Austria & Schlierbach/Au 2 & $14^{\circ} 06^{\prime}$ & $47^{\circ} 54^{4}$ & 10 \\
\hline 7 & Austria & Raxalpe/Reichenau & $15^{\circ} 48^{\prime}$ & $47^{\circ} 42^{\prime}$ & 4 \\
\hline 8 & Austria & I inz & $14^{\circ} 17^{\prime}$ & $48^{\circ} 18^{\prime \prime}$ & 3 \\
\hline 9 & Bulgaria & Sofia & $23^{\circ} 18^{\prime}$ & $42^{\circ} 42^{\prime}$ & 11 \\
\hline 10 & Bulgaria & Stara l'lanina & $25^{\circ} 19^{\prime}$ & $42^{\circ} 47^{\prime}$ & 8 \\
\hline 11 & Czech Republic & Lovos/Loyosice & $14^{\circ} 06^{\prime}$ & $50^{\circ} 30^{\circ}$ & 10 \\
\hline 12 & Czcch Republic & So-Hong Oblik/Louny & $13^{\circ} 48^{\prime}$ & $50^{\circ} 24^{\prime}$ & 10 \\
\hline 13 & Czech Republic & Velky VIcb/Louny & $13^{\circ} 48^{\prime}$ & $50^{\circ} 24^{\top}$ & 8 \\
\hline 14 & Denmark & Arbus & $10^{\circ} 13^{\prime}$ & $56^{\circ} 09^{\prime}$ & 4 \\
\hline 15 & France & Bordeaux & $-0^{\circ} 42^{\prime}$ & $44^{\circ} 48^{\prime}$ & 11 \\
\hline 16 & France & La Brede/Bordeaux & $-0^{\circ} 36^{\prime}$ & $44^{\circ} 42^{\prime}$ & 10 \\
\hline 17 & France & I a Teste & $-1^{\circ} 12^{\prime}$ & $44^{\circ} 36^{\prime}$ & 2 \\
\hline 18 & France & Lussac Les Chaleau/Vienne & $0^{\circ} 48^{\prime}$ & $46^{\circ} 24^{\prime}$ & 2 \\
\hline 19 & France & Avignon & $5^{\circ} 05^{3}$ & $43^{\circ} 56^{\prime}$ & 6 \\
\hline 20 & Georgian Republic & Bantsurtkari/Dusheti Region & $44^{\circ} 36^{\prime}$ & $42^{\circ} 06^{\circ}$ & 4 \\
\hline 21 & Georgian Republic & Lagodekhi Region & $46^{\circ} 18^{\prime}$ & $41^{\circ} 48^{\prime}$ & 5 \\
\hline 22 & Georgian Republic & Zestaponi Region & $43^{\circ} 00^{\prime}$ & $42^{\circ} 06^{\top}$ & 5 \\
\hline 23 & Gcrmany & Seidcwitztal/Licbstadt & $13^{\circ} 52^{\prime}$ & $50^{\circ} 54^{\prime}$ & 10 \\
\hline 24 & Germany & Tharandter Burgberg & $13^{\circ} 35^{\prime}$ & $50^{\circ} 57^{*}$ & 9 \\
\hline 25 & Germany & Bad Driburg & $9^{\circ} 03^{\prime}$ & $51^{\circ} 45^{\prime}$ & 9 \\
\hline 26 & Germany & Ilagen/Rügen & $13^{\circ} 34^{\prime}$ & $54^{\circ} 34^{\prime}$ & 10 \\
\hline 27 & Germany & Schönberg & $11^{\circ} 08^{\prime}$ & $53^{\circ} 52^{\prime}$ & 7 \\
\hline 28 & Germany & Strelitz/Düsterförde & $13^{\circ} 07^{\prime}$ & $53^{\circ} 15^{4}$ & 10 \\
\hline 29 & Germany & Kleve & $6^{\circ} 09^{\circ}$ & $51^{\circ} 48^{\prime}$ & 9 \\
\hline 30 & Germany & Kinding/Altmïhltal & $11^{\circ} 23^{\prime}$ & $49^{\circ} 00^{\circ}$ & 9 \\
\hline 31 & Germany & Heyda & $10^{\circ} 54^{4}$ & $50^{\circ} 45^{\top}$ & 5 \\
\hline 32 & Germany & Mühlberg & $10^{\circ} 48^{\prime}$ & $50^{\circ} 51^{\prime}$ & 5 \\
\hline 33 & Germany & Mettmann & $6^{\circ} 57^{\prime}$ & $51^{\circ} 15^{\top}$ & 9 \\
\hline 34 & Germany & Dankerode & $1 L^{\circ} 09$ & $51^{\circ} 36^{\prime}$ & 3 \\
\hline 35 & Germany & Bad Münstereifel & $6^{\circ} 45^{\prime}$ & $50^{\circ} 36^{*}$ & 10 \\
\hline 36 & Germany & Jessen MeiBner Elbta] & $13^{\circ} 30^{\prime}$ & $51^{\circ} 12^{*}$ & 10 \\
\hline 37 & Germany & Bad Kösen & $11^{\circ} 42^{\prime}$ & $51^{\circ} 12^{4}$ & 9 \\
\hline 38 & Germany & Vockerode & $12^{\circ} 21^{\prime}$ & $51^{\circ} 48$ & 10 \\
\hline 39 & Germany & Pegnitz/Laufamholz & $11^{\circ} 12^{\prime}$ & $49^{\circ} 30^{\prime}$ & 9 \\
\hline 40 & Germany & Freising/lsar & $11^{\circ} 47^{\prime}$ & $48^{\circ} 24^{\prime}$ & 10 \\
\hline 41 & Gcrmany & Elmstcin & $7^{\circ} 54^{\prime}$ & $49^{\circ} 21^{\prime}$ & 10 \\
\hline 42 & Germany & Brieskow Finkenheerd & $14^{\circ} 36^{\prime}$ & $52^{\circ} 18^{\top}$ & 8 \\
\hline 43 & Germany & Frankfür (Oder) & $14^{\circ} 33^{\prime}$ & $52^{\circ} 18^{\prime}$ & 10 \\
\hline 44 & Germany & Hann. Münden & $9^{\circ} 42^{\prime}$ & $51^{\circ} 24^{4}$ & 9 \\
\hline 45 & Germany & Freiburg & $7^{\circ} 48^{\prime}$ & $48^{\circ} 00^{\circ}$ & 5 \\
\hline
\end{tabular}


Table 1. - Continued.

\begin{tabular}{|c|c|c|c|c|c|}
\hline 46 & Germany & Btemen/Aumund & $8^{\circ} 49^{\prime}$ & $53^{\circ} 05^{\prime}$ & 4 \\
\hline 47 & Germany & Merl, Krejs Soest & $7^{\circ} 55^{\prime}$ & $51^{\circ} 33^{\prime}$ & 3 \\
\hline 48 & Gcrmany & Menden, Oesbert & $7^{\circ} 48^{\prime}$ & $51^{\circ} 26^{\prime}$ & 9 \\
\hline 49 & Germany & Beckum, Hellbach & $8^{\circ} 02^{\prime \prime}$ & $5 l^{\circ} 45^{\prime}$ & 5 \\
\hline 50 & Gcrmany & Esscn & $7^{\circ} 00^{\prime}$ & $51^{\circ} 24^{\prime}$ & 10 \\
\hline 51 & Greece & Filakion & $26^{\circ} 17^{\prime}$ & $41^{\circ} 42^{\prime}$ & 5 \\
\hline 52 & Hungary & Kapuwar/Vitnied & $17^{\circ} 00^{\circ}$ & $47^{\circ} 35^{\prime}$ & 9 \\
\hline 53 & 1 lungary & Gerecse Mountains & $18^{\circ} 26^{\circ}$ & $47^{\circ} 39^{\prime}$ & 10 \\
\hline 54 & Hungary & Tokaj/Tisza & $21^{\circ} 23^{\prime}$ & $48^{\circ} 09^{\prime}$ & 9 \\
\hline 55 & Hungary & Pecs & $18^{\circ} 13^{\prime}$ & $46^{\circ} 05^{\prime}$ & 2 \\
\hline 56 & Iran & Teleran/Elbrus & $51^{\circ} 18^{\circ}$ & $35^{\circ} 36^{\prime}$ & 9 \\
\hline 57 & Italy & Meran & $11^{\circ} 06^{\prime}$ & $46^{\circ} 42^{\prime}$ & 23 \\
\hline 58 & Italy & Tuscania & $11^{\circ} 48^{\prime}$ & $42^{\circ} 24^{\prime}$ & 9 \\
\hline 59 & Italy & Cilento National Park & $15^{\circ} 18^{\prime}$ & $40^{\circ} 03^{\prime}$ & 9 \\
\hline 60 & Italy & Vesuv & $14^{\circ} 24^{\prime}$ & $40^{\circ} 48^{\prime}$ & 9 \\
\hline 61 & Italy & Lustra & $15^{\circ} 00^{\prime}$ & $41^{\circ} 12^{\prime}$ & 3 \\
\hline 62 & Italy & Milano & $8^{\circ} 48^{\prime}$ & $45^{\circ} 30^{\prime}$ & 9 \\
\hline 63 & Kosovo & Grebno/Pristina & $21^{\circ} 11^{\circ}$ & $42^{\circ} 20^{\prime}$ & 11 \\
\hline 64 & Macedonia & Ohrid & $20^{\circ} 55^{\circ}$ & $41^{\circ} 12^{\prime}$ & 10 \\
\hline 65 & Moldova & Schepte-Ban & $27^{\circ} 19^{\circ}$ & $47^{\circ} 52^{\prime}$ & 9 \\
\hline 66 & Moldova & Prisacani & $27^{\circ} 57^{\prime}$ & $47^{\circ} 04^{\prime}$ & 10 \\
\hline 67 & Poland & Krapkowice & $17^{\circ} 55^{\prime}$ & $50^{\circ} 29^{\prime}$ & 10 \\
\hline 68 & Poland & Rogozno Zamek & $18^{\circ} 57^{\prime}$ & $53^{\circ} 31^{\prime}$ & 8 \\
\hline 69 & Romania & Pesteana & $22^{\circ} 48^{\circ}$ & $45^{\circ} 32^{\prime}$ & 10 \\
\hline 70 & Romania & Bukarest/Pietrele & $26^{\circ} 06^{\circ}$ & $44^{\circ} 06^{\prime}$ & 6 \\
\hline 71 & Romania & Fägăras & $24^{\circ} 35^{\circ}$ & $45^{\circ} 41^{\prime}$ & 5 \\
\hline 72 & Romania & Bahluj & $26^{\circ} 54^{\prime}$ & $47^{\circ} 05^{\prime}$ & 9 \\
\hline 73 & Romania & Galgau & $23^{\circ} 44^{\prime \prime}$ & $47^{\circ} 15^{\prime}$ & 11 \\
\hline 74 & Serbia & Novi Sad & $19^{\circ} 22^{\prime}$ & $45^{\circ} 16^{\prime}$ & 10 \\
\hline 75 & Serbia & Belgrad & $20^{\circ} 27^{\prime}$ & $44^{\circ} 09^{\prime}$ & 8 \\
\hline 76 & Slovakia & Hrabusice/Slovakian Paradise & $20^{\circ} 24^{\prime}$ & $48^{\circ} 57^{\prime}$ & 10 \\
\hline 77 & Slovakia & Donovaly/Lower Tatra & $19^{\circ} 12^{\prime}$ & $49^{\circ} 03^{\prime}$ & 6 \\
\hline 78 & Slovakia & Poprad & $20^{\circ} 18^{\circ}$ & $49^{\circ} 12^{\prime}$ & 6 \\
\hline 79 & Slovakia & Bratislava/Ostrove & $17^{\circ} 29^{\circ}$ & $47^{\circ} 56$ & 10 \\
\hline 80 & Slovakia & Kosice & $21^{\circ} 09^{\circ}$ & $48^{\circ} 41^{\prime}$ & 4 \\
\hline 81 & Slovenia & Ljubljana/Vir & $14^{\circ} 37^{\prime}$ & $46^{\circ} 08^{\prime}$ & 9 \\
\hline 82 & Slovenia & Maribor/Starse & $15^{\circ} 43^{\circ}$ & $46^{\circ} 30^{\prime}$ & 10 \\
\hline 83 & Spain & Sales Ielos Inantes & $-4^{\circ} 00^{\prime}$ & $39^{\circ} 48^{\prime}$ & 2 \\
\hline 84 & Spain & Perales de Alfambra & $-1^{0} 00^{3}$ & $40^{\circ} 42^{\prime}$ & 5 \\
\hline 85 & Switzerland & Uetliberg Adliswil/Zürich & $8^{\circ} 30^{\circ}$ & $47^{\circ} 18^{\prime}$ & 5 \\
\hline 86 & Switzcrland & Lägeren Spreitenbach & $821^{\prime}$ & $47^{\circ} 24^{\prime}$ & 8 \\
\hline
\end{tabular}

The intended number of 10 individuals could not be realised in every case. A total of 86 populations and 673 individuals were sampled (average 7.8 individuals per population, range $2 \ldots 23$ ). Fresh leave samples were frozen at $-80^{\circ} \mathrm{C}$ or dried at $40^{\circ} \mathrm{C}$ until DNA extraction.

\section{DNA extraction and PCR-RFLP analysis}

The isolation of total DNA from leaves followed a modified CTAB protocol (DUMoLIN et al., 1995). The amplification of noncoding regions of chloroplast DNA based on a selection of eight consensus primer pairs (Table 2). These primer pairs were successfully applied on 20 other woody species (GRIVET et al., 2001).

Amplification reactions contained $1 \mathrm{x}$ PCR buffer with $2.5 \mathrm{mM} \mathrm{MgCl}_{2}$ (AppliChem Darmstadt), $250 \mu \mathrm{M}$ dNTP-mix, $0.5 \mu \mathrm{M}$ of each primer, $1 \mathrm{U}$ Taq Polymerase (AppliChem Darmstadt) and $20-100 \mathrm{ng}$ template DNA in a volume of $25 \mu \mathrm{l}$. Polymerase chain reactions (PCR) were carried out in a Biometra thermal cycler using the following conditions: 1 cycle with $95^{\circ} \mathrm{C} / 5 \mathrm{~min}, 30$ cycles with $95^{\circ} \mathrm{C} / 45$ sec denaturation, annealing temperature $/ 45 \mathrm{sec}$, and $72^{\circ} \mathrm{C} /$ elongation time (Table 2), and $7 \mathrm{~min}$ final elongation at $72^{\circ} \mathrm{C}$. The presence of a PCR product of expected length was checked with agarose gel electrophoresis. Amplification products were digested with AfaI, HhaI, HindIII, HinfI, MboI, MspI, SspI, TaqI and XbaI in according to manufacture's instructions to find out variation in restriction sites and/or fragment length. RFLP fragments were separated with agarose gel electrophoresis and stained with ethidium bromide. Gels were photographed with the Kodak EDAS 290 system.

A preliminary screening of samples representing all geographic regions was carried out to find combinations of primers and restriction enzymes revealing polymorphisms. This subset of 30 samples from 30 locations in 14 countries resulted in 6 haplotypes. The informative combinations were then used to screen all Cornus sanguinea populations. Two additional haplotypes appeared later by further combinations of known polymorphic sites. 
Table 2. - Primer pairs tested for red dogwood.

\begin{tabular}{|c|c|c|c|c|c|}
\hline $\begin{array}{l}\text { Primer pair } \\
\text { abbreviation }\end{array}$ & $\begin{array}{l}\text { Chloroplast } \\
\text { DNA region }\end{array}$ & Reference & $\begin{array}{l}\text { Annealing } \\
\text { temperature } \\
\left({ }^{\circ} \mathrm{C}\right) \\
\end{array}$ & $\begin{array}{l}\text { Elongation } \\
\text { time (min) }\end{array}$ & $\begin{array}{l}\text { Length of l'CR } \\
\text { product in } \\
\text { tobacco (bp) }\end{array}$ \\
\hline AS & PsbA - tans & $\begin{array}{l}\text { DEMESURE et al. } \\
(1995)\end{array}$ & 58 & 4 & 3681 \\
\hline B2B3 & PsbB - pctB & $\begin{array}{l}\text { GRJVET ct al. } \\
(2001)\end{array}$ & 53 & 3 & 2781 \\
\hline $\mathrm{CD}$ & $\operatorname{tm} C-\operatorname{tm} D$ & $\begin{array}{l}\text { DEMESURE ef al. } \\
(1995)\end{array}$ & 58 & 4 & 3167 \\
\hline DT & $\tan D-\tan T$ & $\begin{array}{l}\text { DEMESURE et al. } \\
(1995)\end{array}$ & 55 & 2 & 1213 \\
\hline HK & $\operatorname{trnH}-\operatorname{trn} K$ & $\begin{array}{l}\text { DEMESURE ct al. } \\
(1995)\end{array}$ & 62 & 2 & 1831 \\
\hline $\mathrm{K} 1 \mathrm{~K} 2$ & $\operatorname{trn} K-\operatorname{trn} K$ & $\begin{array}{l}\text { DEMESURE et al. } \\
(1995)\end{array}$ & 53 & 3 & 2585 \\
\hline TF & $\operatorname{tm} T-\operatorname{trn} F^{2}$ & $\begin{array}{l}\text { TABFRI FT et al. } \\
(199 \mathrm{~d})\end{array}$ & 58 & 2 & 1754 \\
\hline VL & $\tan V-\operatorname{tbcL}$ & $\begin{array}{l}\text { DLMOLIN- } \\
\text { LAPEGUE et al. } \\
\text { (1997b) }\end{array}$ & 57.5 & 4 & 3850 \\
\hline
\end{tabular}

\section{Data evaluation}

All combinations of primers and restriction enzymes with variation in RFLP patterns were scored for their polymorphic sites, which are the presence or absence of a restriction site or length variations of DNA fragments. Haplotypes were defined as certain combinations of polymorphic sites.

Two methods were applied to visualise the genetic relationships between haplotypes. Firstly, a dendrogram was constructed from genetic distances (SAS Institute Inc., 2003). Secondly, a minimum spanning tree was created with help of the software Arlequin (SCHNEIDER et al., 2000).

The parameters $\mathrm{H}_{T}$ (total diversity) and $\mathrm{H}_{\mathrm{S}}$ (mean value of levels of diversity within populations) characterise the genetic variation of haplotypes within the range between 0 and 1 . Parameters for genetic differentiation among populations of haploid data were described by Pons and PeTIT (1995). $\mathrm{G}_{\mathrm{ST}}$ is a parameter between 0 in case of total identity of all populations and 1 in case of lack of consistencies and measures the differentiation between populations from haplotype frequency data. NST additionally includes the genetic distances between haplotypes available from the coded polymorphic sites. The software
PermutCpSSR (Version 2.0, http://www.pierroton.inra.fr/ genetics/labo/Software/) calculates $\mathrm{G}_{\mathrm{ST}}$ and $\mathrm{N}_{\mathrm{ST}}$ for populations with at least 3 individuals. Additionally it tests whether $G_{\mathrm{ST}}$ and $\mathrm{N}_{\mathrm{ST}}$ significantly differ to detect a phylogeographic structure by a permutation procedure (Pons and PETIT, 1996; BURBAN et al., 1999). These parameters are common used in numerous plant organelle studies and allowed a comparison of variation levels between species.

\section{Results}

\section{Identification of cpDNA haplotypes}

Seven of eight tested primer pairs resulted in amplification products of the expected length. No or faint bands were observed for the primer pair TF. PCR products of the two primer pairs DT and HK exhibit length variations between genetic variants. Eight different haplotypes were recognized by combinations of PCR-RFLP patterns. Fragments were described as F1, F2, ... with descending length. Variations in fragment length were coded by 1 for the fragment with the maximum length followed by 2 for the next shorter fragment and so on. Examples are given in Figure 2. The presence resp.

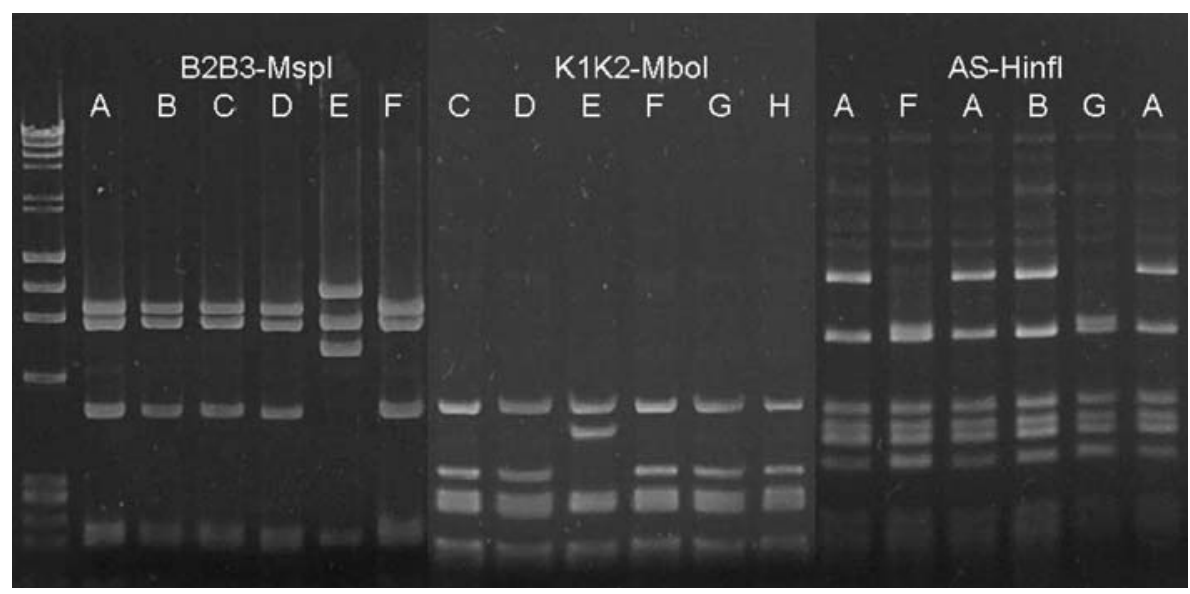

Figure 2. - Examples of PCR-RFLP patterns. 
absence of a restriction site was coded with 1 and 0 . Table 3 displays 17 PCR-RFLP patterns with together 21 non-redundant polymorphic sites.

The genetic relationships among the eight haplotypes are displayed in Figure 3. Their genealogy inferred from 21 polymorphic sites is very similar with both methods, the minimum spanning tree (Figure $3 a$ ) and the UPGMA cluster dendrogram (Figure $3 b$ ). The common European haplotype A is closely related to haplotypes B and C. The only differences exist in the total length of the trnH-trnK fragment and one restriction site in the trnC-trnD region. Another group of closely related haplotypes is formed from type F, G and $\mathrm{H}$. These three haplotypes distinguish in 3 to 4 polymorphic sites in several regions. Haplotype D from the Caucasian region is related to both mentioned groups with at least two different sites and could be their ancestor. Haplotype E from the Balkan Peninsula is derived from haplotype D by a high number of mutation steps and is genetically far distant from all other haplotypes.

\section{Haplotype variation in Europe}

A total of 673 samples from 86 populations belonging to 22 countries were analysed for their cpDNA haplotype. Haplotype A strongly dominates in the whole distribution area. It takes nearly 90 percent whereas the remaining seven haplotypes together come to approx. 10 percent (Table 4). The total genetic variation $\mathrm{H}_{\mathrm{T}}$ is low $\left(\mathrm{H}_{\mathrm{T}}=0.190\right)$. The mean within population diversity $H_{S}$ is low as well $\left(H_{S}=0.051\right)$. Based on this low level of genetic variation, the portion of differentiation among populations amounts to $\mathrm{G}_{\mathrm{ST}}=0.732$. The parameter $\mathrm{N}_{\mathrm{ST}}$, which takes into account the genetic relatedness of single haplotypes, is slightly lower $\left(\mathrm{N}_{\mathrm{ST}}=0.730\right)$, but not significantly different from $\mathrm{G}_{\mathrm{ST}}$.

Five of seven rare haplotypes exist only in one geographic place (Figure 4): haplotype D (dark blue) in a Caucasian population, haplotype B (red) in one Slovakian population, haplotype $\mathrm{H}$ (black) in one place in Austria, haplotype $\mathrm{C}$ (pink) in two neighbouring locations in the Czech Republic, and haplotype G (brown) in South West France. In most populations these private haplotypes appear together with the common haplotype A (yellow).

The two remaining rare haplotypes initially differ from this pattern. Haplotype E (light blue) occurs in two neighbouring locations on the Balkan Peninsula, in two populations in central Germany and in one population in Italy. Haplotype $\mathrm{F}$ (green) was detected in two neighbouring Slovakian populations and two locations in the northern part of Germany. The geographic distribution of these two haplotypes induced the assumption that the mentioned German populations are completely or partially introduced from southern regions because there is no indication for stepping stones of a natural migration. In case of haplotype F (green) this suspicion was validated by enquiries of the local responsibility for gene preservation.

Table 3. - Coding Cornus sanguinea cpDNA haplotypes by 21 polymorphic sites.

\begin{tabular}{|c|c|c|c|c|c|c|c|c|c|c|c|c|c|c|c|c|c|c|c|c|c|c|}
\hline \multirow{3}{*}{ 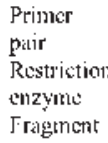 } & \multicolumn{3}{|c|}{$A S$} & \multicolumn{3}{|c|}{ (32B3 } & \multicolumn{6}{|c|}{$\mathrm{CD}$} & \multicolumn{2}{|c|}{ DT } & \multicolumn{3}{|c|}{ IIK } & \multicolumn{2}{|c|}{$\mathrm{K} L \mathrm{~K} 2$} & \multirow{2}{*}{\multicolumn{3}{|c|}{$\begin{array}{l}\text { VL } \\
\text { I thit }\end{array}$}} \\
\hline & I linfl & MspI & SspI & & & & I Ihiti & & & & & $\mathrm{pl}$ & Hitut & & PCR & | 1 15ind & & $A F I$ & Mtool & & & \\
\hline & $\mathrm{FI}$ & $\Gamma \mathbf{I}$ & $\mathrm{T} 2$ & 53 & $F \xi$ & FI & $\mathrm{F} 3$ & $\sqrt{6}$ & $F 1$ & $\mathrm{~F}$ & Fl & 52 & $F 1$ & $\mathrm{Fl}$ & & $\mathrm{T} 2$ & $\Gamma 2$ & $F_{3}$ & $\sqrt{2}$ & FI & & $\Gamma^{2}$ \\
\hline$A$ & 1 & I & 1 & 1 & 1 & 2 & 1 & 2 & 1 & 1 & 2 & 1 & 2 & 2 & 2 & 1 & 1 & 1 & 2 & 1 & & 2 \\
\hline$B$ & I & I & 1 & 1 & $\mathrm{I}$ & 2 & 1 & 2 & 1 & 1 & 2 & 1 & 2 & 2 & 3 & 1 & 1 & $\mathrm{I}$ & 2 & 1 & & 2 \\
\hline $\mathrm{C}$ & 1 & I & 1 & 1 & 1 & 2 & 0 & 2 & 1 & 1 & 2 & 1 & 2 & 2 & 4 & 1 & 1 & 1 & 2 & 1 & & 2 \\
\hline $\mathrm{D}$ & I & I & 1 & 1 & $\mathrm{I}$ & 2 & I & 2 & 1 & 1 & 2 & 1 & 1 & 2 & 2 & 1 & 0 & 1 & 2 & 1 & 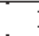 & 2 \\
\hline $\mathrm{F}$ & 1 & $?$ & 2 & 2 & 0 & 1 & 0 & 2 & 1 & 0 & 2 & 2 & 3 & 1 & 2 & 0 & 0 & 0 & 1 & 0 & . & ] \\
\hline$F$ & 2 & 2 & 1 & 1 & 1 & 2 & 0 & 1 & 2 & 1 & 1 & 0 & 1 & 2 & 2 & 0 & 1 & 1 & 2 & 1 & . & 2 \\
\hline $\mathrm{G}$ & 2 & I & 1 & 1 & 1 & 2 & 0 & 3 & 2 & 1 & 1 & 0 & 1 & 2 & 2 & 0 & 0 & 1 & 2 & 1 &. & 2 \\
\hline $\mathrm{H}$ & 1 & I & 1 & 1 & 0 & 2 & 0 & 3 & 2 & 1 & 1 & 0 & $?$ & $?$ & 1 & 0 & 1 & 1 & 2 & 1 & & 2 \\
\hline
\end{tabular}

a)

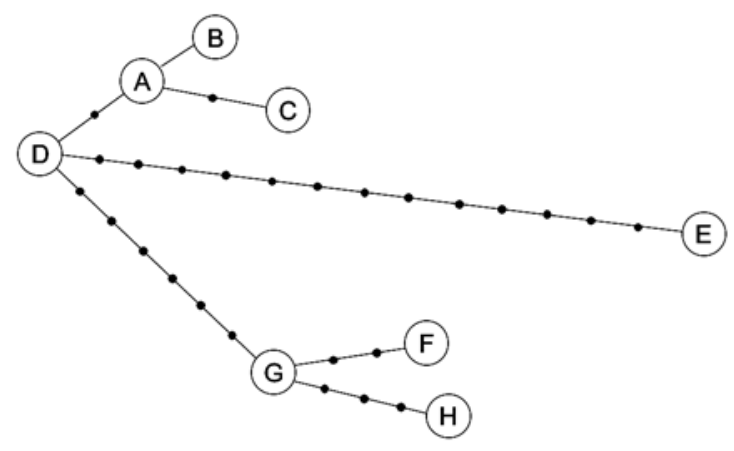

b)

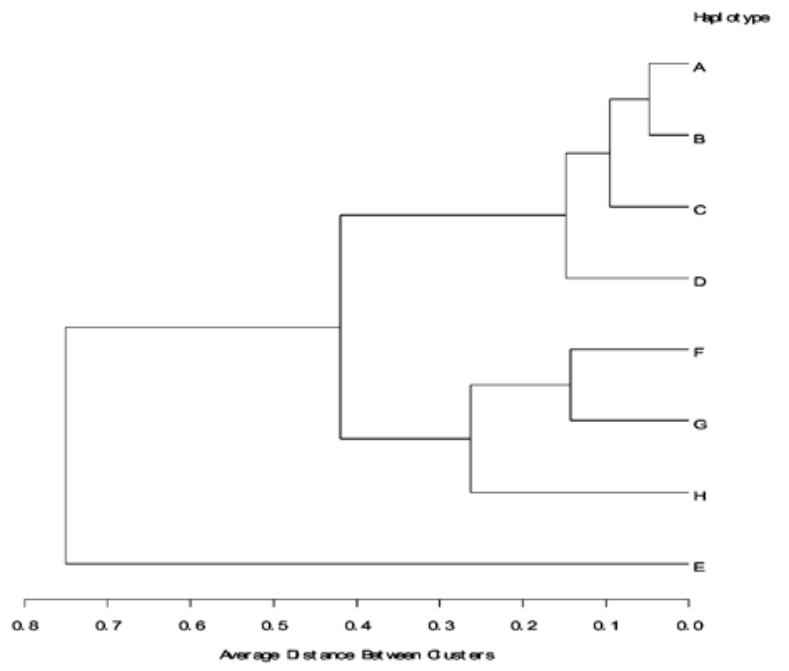

Figure 3. - a) Minimum spanning tree and b) UPGMA cluster dendrogram based on genetic distance. 
Table 4. - Absolute frequencies of cpDNA haplotypes in European Cornus sanguinea populations (71 populations with exclusively haplotype A are pooled, see Table 1 for their description).

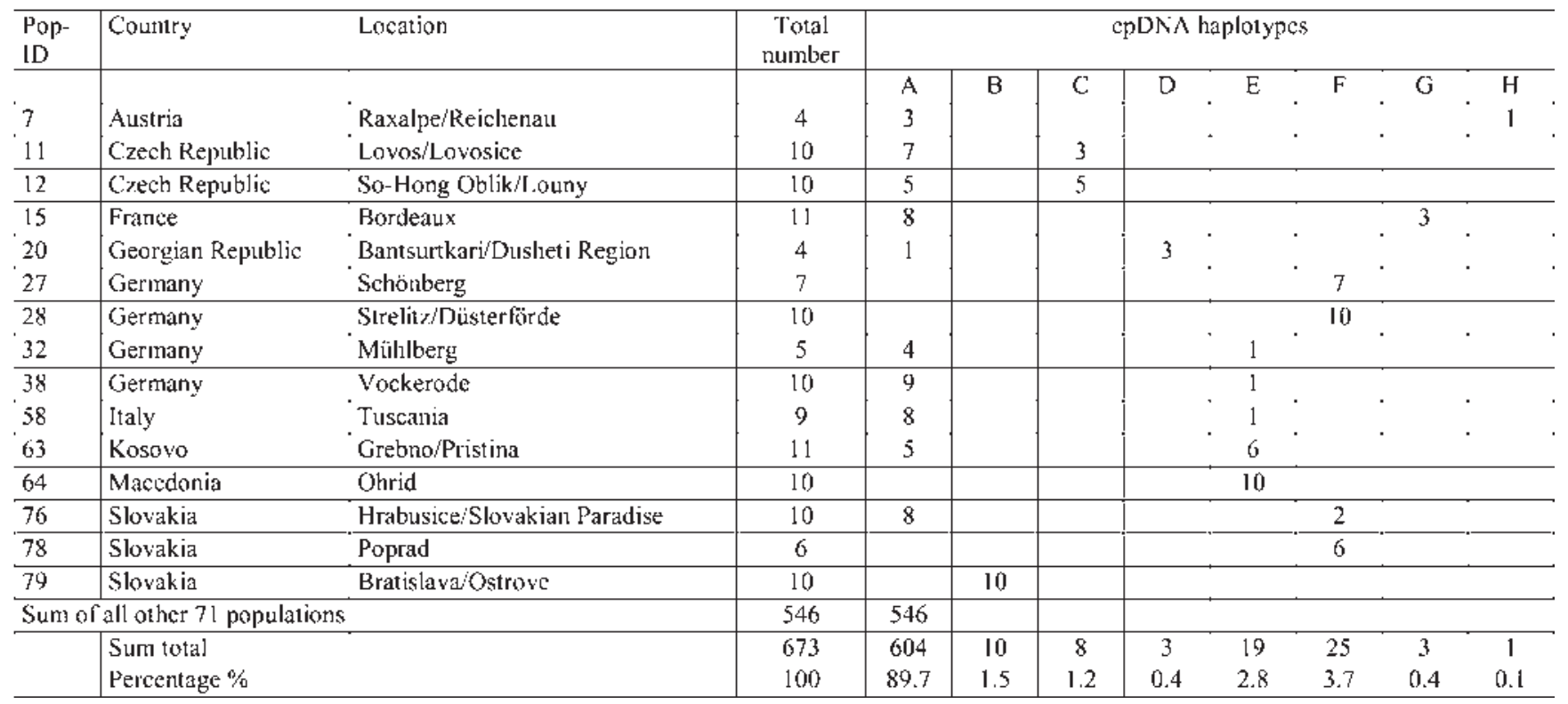

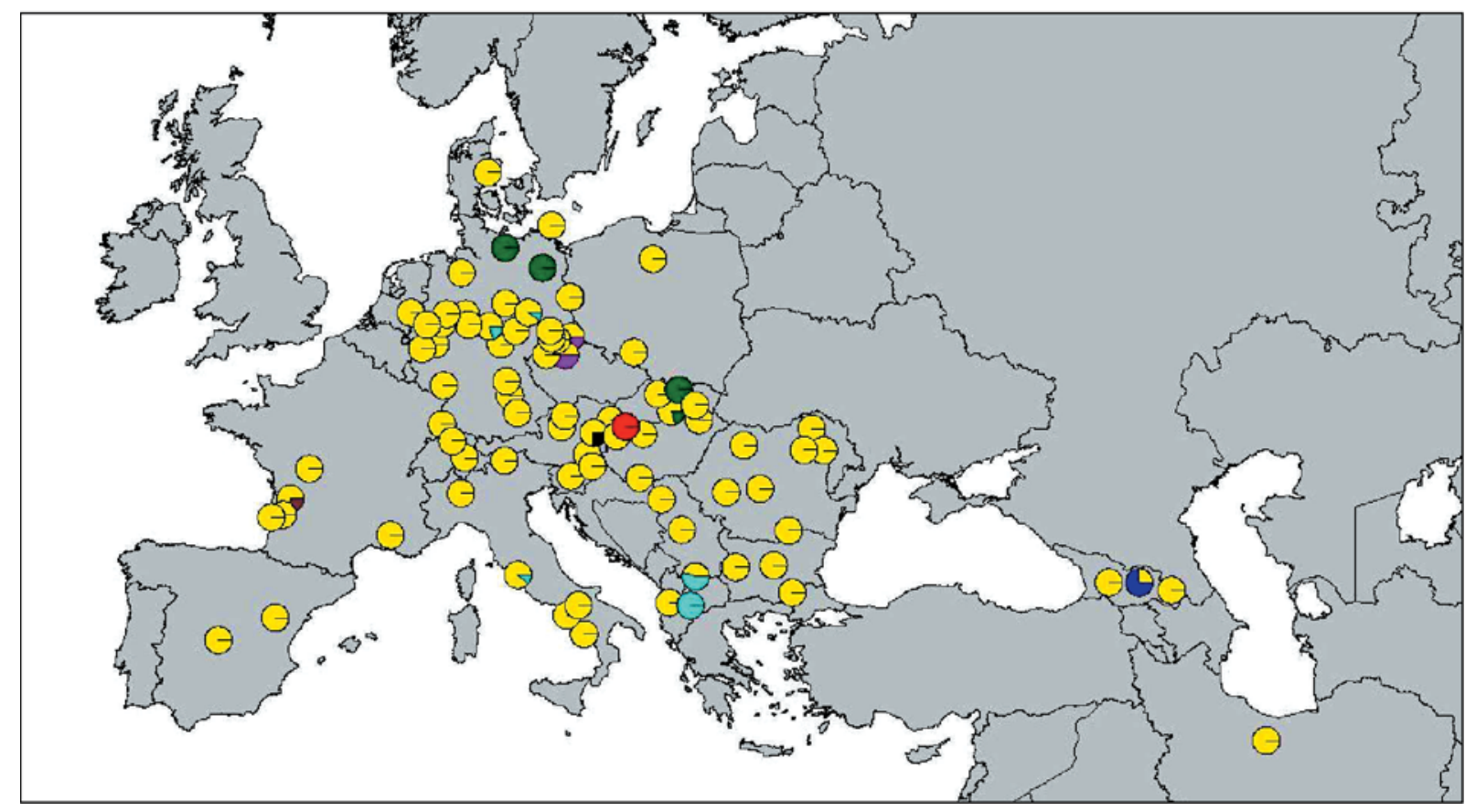

Figure 4. - Geographic distribution of eight chloroplast haplotypes identified in Cornus sanguinea (for populations see Table 1, haplotype $\mathrm{A}=$ yellow, $\mathrm{B}=$ red, $\mathrm{C}=$ pink, $\mathrm{D}=$ dark blue, $\mathrm{E}=$ light blue, $\mathrm{F}=$ green, $\mathrm{G}=$ brown, $\mathrm{H}=$ black).

Both populations in northern Germany were established in the 1960s with plant material from Slovakia (personal communication, W. Vотн, Mecklenburg-Western Pomerania). For the populations Mühlberg and Vockerode with haplotype E (light blue) it is strongly assumed that they originate at least partially from introduced material from the Balkan Peninsula. No explanation could be given for the existence of haplotype $\mathrm{E}$ in one population in Italy.

A recalculation of variation parameters without the four German populations that were obviously introduced resulted in a reduced total variation of $\mathrm{H}_{\mathrm{T}}=0.147$. The values of $\mathrm{G}_{\mathrm{ST}}$ and $\mathrm{N}_{\mathrm{ST}}$ amount to 0.687 and 0.704 , respectively.

\section{Discussion}

The cpDNA variation was assessed to be low in Cornus sanguinea. Regardless of the detected variation in 7 noncoding regions of chloroplast DNA evenly spread over the large single copy region, a low number of 8 cpDNA haplotypes was identified. This is in contrast to for example Quercus $s p$. with 33 haplotypes found with 4 noncoding regions (PETIT et al., 2002), 
Prunus spinosa with 32 haplotypes found with 3 noncoding regions (MoHANTy et al., 2002) or Populus nigra with 83 haplotypes detected in 5 noncoding regions (CotTRELL et al., 2005) by the PCR-RFLP method. One example, Carpinus betulus, could be found with a similar low number of haplotypes even by testing many noncoding regions (GRIVET and PETIT, 2003).

The only other European species in the genus Cornus, $C$. mas, is unable to cross with Cornus sanguinea, therefore an interspecific hybridisation for Cornus can not contribute to variation. Likewise no other species is present in the genus Carpinus. More chances exist to distribute organelle haplotypes by hybridisation events for other genera with crossable species (i. e. Quercus: Petit et al., 2002; Betula: Palmé et al., 2004) with different ecological demands or only partially overlapping distribution areas.

The Cornus sanguinea haplotypes are divided into 3 groups of related types. The first group consisting of haplotypes A, B, $\mathrm{C}$ and D (see Figure 3) cover the putative ancestor D and the most abundant haplotype A. The second group is composed of haplotypes F, G and H. Haplotype $\mathrm{E}$ is single and exhibits the largest genetic distance to all other haplotypes. There is no association between these 3 groups and their geographic occurrence within the tested material.

Besides the low number of haplotypes the total genetic variation $\mathrm{H}_{\mathrm{T}}=0.15$ is lower in Cornus sanguinea than in 11 European tree species, where $\mathrm{H}_{\mathrm{T}}$ ranges from 0.46 to 0.86 (reviewed in FinkeldeY et al., 2005) or in 8 other European shrub species, where $\mathrm{H}_{\mathrm{T}}$ ranges from 0.26 to 0.97 (reviewed in LIESEBACH et al., 2007).

Life history traits of 29 tree and shrub species (without Cornus) and their chloroplast DNA variation levels between populations $\left(\mathrm{G}_{\mathrm{ST}}\right.$ and $\left.\mathrm{N}_{\mathrm{ST}}\right)$ were reviewed by AGUinaGALDE et al. (2005). For several species the PCR-RFLP method was completed by chloroplast microsatellite loci. Cornus sanguinea is a shrub with a mixed sexual and vegetative reproduction, with biotic pollination and its seeds are dispersed by animal ingestion. For species with these traits the average $\mathrm{G}_{\mathrm{ST}}$ ranges from 0.38 to 0.43 and the average $\mathrm{N}_{\mathrm{ST}}$ from 0.42 to 0.47 (AGUINAGALDE et al., 2005). The observed values of $\mathrm{G}_{\mathrm{ST}}=0.69$ and $\mathrm{N}_{\mathrm{ST}}=0.70$ for Cornus sanguinea in this study are more in accordance to species of opposite traits with exclusively sexual reproduction, wind pollination and a seed dispersal by wind or animal caching (average $\mathrm{G}_{\mathrm{ST}} \quad 0.56 \ldots 0.83$, average $\mathrm{N}_{\mathrm{ST}}$ $0.62 \ldots 0.83)$. A possible explanation for this atypical behaviour of Cornus sanguinea could be its absolute lowest $\mathrm{H}_{\mathrm{T}}$ in the entire tree and shrub species collection, so that the scale to compare $\mathrm{G}_{\mathrm{ST}}$ and $\mathrm{N}_{\mathrm{ST}}$ could be skewed.

Other species with low $\mathrm{H}_{\mathrm{T}}$ are Crataegus monogyna $\left(\mathrm{H}_{\mathrm{T}}=\right.$ 0.26 ) and Fagus sylvatica $\left(\mathrm{H}_{\mathrm{T}}=0.27\right)$. In both cases only 3 microsatellite sites and 21 to 23 populations were included to identify 4 resp. 6 haplotypes (PETIT et al., 2003). There can only be speculations about, if more polymorphic sites would have resulted in more total variation. In case of Fagus sylvatica a former survey with PCR-RFLPs in 85 populations yielded in 11 haplotypes, but the total diversity was low as well $\left(\mathrm{H}_{\mathrm{T}}=0.24\right)$ (DEMESuRE et al., 1996).

Thus, the greatest analogies of Cornus sanguinea were observed to Fagus sylvatica and also to Frangula alnus (HAMPE et al., 2003) regarding the nearly uniform chloroplast haplotype structure in the temperate Europe, even though Fagus and Frangula possess very divergent reproduction and pollen and seed dispersal traits.

A higher number of chloroplast haplotypes in common refugia of European plant species (Iberian, Apennine and Balkan
Peninsulas, Caucasus region) were reported for several trees and shrubs (PETiT et al., 2003). The lack of a number of haplotypes for Cornus sanguinea in at least one of these refugia could suppose a low variation before the ice age and/or a more or less strong bottleneck during recolonisation.

To get some more information on possible migration histories of Cornus sanguinea, a search in the European pollen database (http://www.ncdc.noaa.gov/paleo/epd/epd_main.html) was carried out additionally. It resulted in only a small number of detections of pollen in sediments in Syria, Turkey, Greece, Slovakia, the Czech Republic, Poland, Switzerland and Sweden and no relationship between geographic location and date. This is not surprising, because red dogwood is an insect pollinated species that releases only few pollen into the atmosphere. The earliest evidence is from Poland 9400 years ago (NoRYAKIEWICZ and RALSKA-JasiewiCzowA, 1989). Fruits of Cornus sanguinea were gathered from humans as it was detected for the Mesolithic period 5600-4000 BC in Denmark (KuBIAKMartens, 1999), the late Mesolithic in Sweden (REgnell et al., 1995) and in middle Neolithic in France (DiETSCH, 1996). But this species was never cultivated like Cornus mas L. In general, fossil verifications are very rare and could not really contribute to clarify the location of glacial refugia and the subsequent postglacial routes of this species after the ice age. Cornus $s p$. in the wild state is widespread in the Caucasus and Crimea and thus ZHUKOVskY (1965) assumed a gene centre here.

The presence of the putative ancestor haplotype $\mathrm{D}$ in the Caucasian region, the derived common haplotype $\mathrm{A}$ in the whole European area and rare types B and C in Czech Republic and Slovakia are in concordance with this hypothesis. Other haplotypes, as the group G-F-H and the most exceptional haplotype E, accumulated many mutation steps and are far distant from the dominating group. Their geographic origin could not be clearly identified with the available data.

No phylogeographic structure could be detected due to the extreme dominance of the common haplotype $\mathrm{A}$ in the whole tested area and the punctiform variation structure of only 11 out of 82 populations excluding the 4 obviously introduced German populations. Likewise no structure could be noticed by pairwise $\mathrm{G}_{\mathrm{ST}}$ that fluctuate between 0.6 and 0.8 for all classes of pairwise geographic distance up to $3000 \mathrm{~km}$. Pairwise $\mathrm{G}_{\mathrm{ST}}$ decreases to 0.5 for distance classes between 3000 and $4000 \mathrm{~km}$ (DistoN, http://www.pierroton.inra.fr/genetics/labo/Software, data not shown).

Other haplotypes than the common type A were detected only in locally restricted areas. Those findings indicate that after the colonisation of the European continent only a very restricted gene flow could have happened. At least populations with rare haplotypes, independently from belonging to one of the 3 groups, persist relatively isolated since no dissemination into surrounding areas with only haplotype A was observed in the sampled material. Deviations from this punctiform structure of variation of present-day populations are mostly explained by recent human influence as it was suggested for the 4 German populations.

Actually, guidelines for conservation and management of Cornus sanguinea in landscape cultivation should consider the putative low gene flow by seed between locations. More detailed information on the amount of gene flow within populations and between neighbouring occurrences are not available at present. This aspect has to be explored in another investigation. Recent studies by APLPs on the second European Cornus species, Cornus mas L., as well support a low and restricted gene flow (WISSEMANN et al., 2007) and a low distance of fruit dispersal (MÜLLER and WissemanN, 2007). 


\section{Acknowledgments}

We would like to thank all colleagues in foreign institutes collaborating and helping with sampling their local dogwood populations: L. Blascó (Zvolen, Slovakia), D. Cogalniceanu (Romania), C. Fraissl and J. GutTenberger (Vienna, Austria), O. Holdenrieder (Zurich, Switzerland), M. Kereselidze (Tbilisi, Georgia), F. Kroiner (Linz, Austria), D. Pilarska (Sofia Bulgaria), A. Proko (Albania), J. Reque Kilchenmann and B. Herrero (Madrid, Spain) and E. TeIssier Du Cros (Avignon, France). Additionally we thank our colleagues in Germany: G. AAS and M. LAUERER (Bayreuth), Mr. ARndt (Hofbieber), R. Baron, W. Kramer, K. Meinhardt, E. Müller, S. Rogall, O. Weigenand and B. Witt (Eberswalde), M. Forstreuther (Berlin), K. Lautenschlager (Enzdorf), H.-P. Schmitt and L. Schulze (Arnsberg), R. TAmm (Hassloch), W. Voth and Mr. Reituff (Schwerin) H. Weiss (Tharandt), C. Wessel (Freiburg) and G. von WÜHLISCH (Großhansdorf). We are grateful to Ms. HANNELORE ENKISCH for their engaged and reliable technical assistance in the laboratory. The study was financially supported by the Bundesministerium für Verbraucherschutz, Ernährung und Landwirtschaft, Germany.

\section{References}

Aguinagalde, I., A. Hampe, A. Mohanty, J. P. Martin, J. Duminil and R. J. Petit (2005): Effects of life-history traits and species distribution on genetic structure at maternally inherited markers in European trees and shrubs. Journal of Biogeography 32: 329-339.

Burban, C., R. J. Petit, E. CARCRefF and H. JaCtel (1999): Rangewide variation of the maritime pine bast scale Matsucoccus feytaudi Duc. (Homoptera: Matsucoccidae) in relation to the genetic structure of its host. Molecular Ecology 8 1593-1602.

Cottrell, J. E., V. Krystufek, H. E. Tabbener, A. D. Milner, T. Connolly, L. Sing, S. Fluch, K. Burg, F. Lefìvre, P. Achard, S. Bordács, K. Gebhardt, B. Vornam, M. J. M. Smulders, A. H. Vanden Broeck, J. Van Slycken, V. Storme, W. Boerjan, S. Castiglione, T. Fossati, N. Alba, D. Agúndez, C. Maestro, E. Notivol, J. Bovenschen and B. C. van DAM (2005): Postglacial migration of Populus nigra L.: lessons learnt from chloroplast DNA. Forest Ecology and Management 206: 71-90.

Demesure, B., B. Comps and R. J. Petit (1996): Chloroplast DNA Phylogeography of the Common Beech (Fagus sylvatica L.) in Europe. Evolution 50: 2515-2520.

Demesure, B., N. Sodzi and R. J. Petit (1995): A set of universal primers for amplification of polymorphic non-coding regions of mitochondrial and chloroplast DNA in plants. Molecular Ecology 4: 129-131.

Dietsch, M. F. (1996): Gathered fruits and cultivated plants at Bercy (Paris), a Neolithic village in a fluvial context. Vegetation History and Archaeobotany 5: 89-97.

Dumolin, S., B. Demesure and R. J. Petit (1995): Inheritance of chloroplast and mitochondrial genomes in pedunculate oak investigated with an efficient PCR method. TAG Theoretical and Applied Genetics 91: 1253-1256.

Dumolin-Lapegue, S., B. Demesure, S. Fineschi, V. L. Corre and R. J. Pетіт (1997a): Phylogeographic Structure of White Oaks Throughout the European Continent. Genetics 146 1475-1487.

Dumolin-Lapegue, S., M. H. Pemonge and R. J. Petit (1997b): An enlarged set of consensus primers for the study of organelle DNA in plants. Molecular Ecology 6: 393-397.

Erhardt, W., E. GÖTZ, N. BÖDEKER and S. SEYBOLD (2000): Zander-Handwörterbuch der Pflanzennamen. Eugen Ulmer Verlag, Stuttgart.

Fineschi, S., D. Salvini, D. Taurchini, S. Carnevale and G. G. VENDRAMIN (2003): Chloroplast DNA variation of Tilia cordata (Tiliaceae). Canadian Journal of Forest Research 33 $2503-2508$
Finkeldey, R., O. Gailing and L. Leinemann (2005): Einführung in die Forstgenetik. Institut für Forstgenetik und Forstpflanzenzüchtung, Georg-August-Universität, Göttingen.

Grivet, D., B. Heinze, G. G. Vendramin and R. J. Petit (2001): Genome walking with consensus primers: application to the large single copy region of chloroplast DNA. Molecular Ecology Notes 1: 345-349.

Grivet, D. and R. J. Petit (2002): Phylogeography of the common ivy (Hedera sp.) in Europe: genetic differentiation through space and time. Molecular Ecology 11: 1351-1362.

Grivet, D. and R. J. PetiT (2003): Chloroplast DNA phylogeography of the hornbeam in Europe: Evidence for a bottleneck at the outset of postglacial colonization. Conservation Genetics 4: 47-56.

Hampe, A., J. Arroyo, P. Jordano and R. J. Petit (2003): Rangewide phylogeography of a bird-dispersed Eurasian shrub: contrasting Mediterranean and temperate glacial refugia. Molecular Ecology 12: 3415-3426.

HEGI, G. (1975): Illustrierte Flora von Mitteleuropa. Paul Parey Verlag, Berlin \& Hamburg.

Heuertz, M., S. Fineschi, M. Anzidei, R. Pastorelli, D. SalviNi, L. Paule, N. Frascaria-Lacoste, O. J. Hardy, X. VekeMANS and G. G. VENDRAMIN (2004): Chloroplast DNA variation and postglacial recolonization of common ash (Fraxinus excelsior L.) in Europe. Molecular Ecology 13: 3437-3452.

KRÜsI, B. O. and M. Debussche (1988): The fate of flowers and fruits of Cornus sanguinea L. in three contrasting Mediterranean habitats. Oecologia (Historical Archive) 74: 592-599.

KubiaK-Martens, L. (1999): The plant food component of the diet at the late Mesolithic (Ertebolle) settlement at Tybrind Vig, Denmark. Vegetation History and Archaeobotany 8: $117-127$.

Leinemann, L., K. Bendixen, D. Kownatzki, H. H. Hattemer, K. LIEPE and G. STENGER (2002): Genetic studies in trees and shrubs for landscape propagation with emphasis on production and certification of reproductive material. Allgemeine Forst und Jagdzeitung 173: 146-152.

LiesebaCh, H., V. Schneck and R. KätZel (2007): Phänotypische und genetische Variation bei Landschaftsgehölzen - Ein Review und Beitrag zur aktuellen Diskussion über Herkunftsgebiete. Naturschutz und Landschaftsplanung 39: 297-303.

Meusel, H., E. J. JÄGer, S. RAuschert and E. Weinert (1978): Vergleichende Chorologie der zentraleuropäischen Flora. VEB Gustav Fischer Verlag, Jena.

MeYer, F. H., U. HeCKer, H.-R. Höster and F.-G. Schroeder (2007): Jost Fitschen Gehölzflora. Quelle \& Meyer Verlag, Wiebelsheim.

Mohanty, A., J. P. Martin and I. Aguinagalde (2002): Population genetic analysis of European Prunus spinosa (Rosaceae) using chloroplast DNA markers. American Journal of Botany 89: $1223-1228$

MÜLLER, S. and V. WissemanN (2007): Untersuchungen zur Kulturgeschichte und Populationsdifferenzierung der Kornelkirsche (Cornus mas L.) im mittleren Saaletal. Mitteilungen der Deutschen Dendrologischen Gesellschaft 92: 86-93.

NoRYAKIEWICZ, B. and M. RALSKA-JASIEWICZOWA (1989): Type Region P-w: Dobrzya-Olsztyn Lake Districts. Acta Palaeobotanica 29: 85-93.

Palme, A. E. and G. G. Vendramin (2002): Chloroplast DNA variation, postglacial recolonization and hybridization in hazel, Corylus avellana. Molecular Ecology 11: 1769-1779.

Palmé, A. E., Q. Su, S. Palsson and M. Lascoux (2004): Extensive sharing of chloroplast haplotypes among European birches indicates hybridization among Betula pendula, $B$. pubescens and B. nana. Molecular Ecology 13: 167-178.

Petit, R. J., I. Aguinagalde, J. L. De Beaulieu, C. Bittkau, S. Brewer, R. Cheddadi, R. A. Ennos, S. Fineschi, D. Grivet, M. Lascoux, A. Mohanty, G. Müller-Starck, 
B. Demesure-Musch, A. E. Palmé, J. P. Martin, S. Rendell and G. G. Vendramin (2003): Glacial Refugia: Hotspots But Not Melting Pots of Genetic Diversity. Science 300: 1563-1565.

Petit, R. J., U. M. Csaikl, S. Bordács, K. Burg, E. Coart, J. E. Cottrell, B. Van Dam, J. D. Deans, S. Dumolin-Lapegue and S. FinESCHI (2002): Chloroplast DNA variation in European white oaks: Phylogeography and patterns of diversity based on data from over 2600 populations. Forest Ecology and Management 156: 5-26.

Pons, O. and R. J. Petit (1996): Measuring and Testing Genetic Differentiation With Ordered Versus Unordered Alleles. Genetics 144: 1237-1245.

Pons, O. and R. J. Petit (1995): Estimation, variance and optimal sampling of gene diversity I. Haploid locus. TAG Theoretical and Applied Genetics 90: 462-470.

Regnell, M., M.-J. Gaillard, T. S. Bartholin and P. Karsten (1995): Reconstruction of environment and history of plant use during the late Mesolithic (Ertebølle culture) at the inland settlement of Bökeberg III, southern Sweden. Vegetation History and Archaeobotany (Historical Archive) 4: 67-91.
RENDELL, S. and R. A. ENNOS (2003): Chloroplast DNA diversity of the dioecious European tree Ilex aquifolium L. (English holly). Molecular Ecology 12: 2681-2688.

RolofF, A. and A. BÄRTels (2006): Flora der Gehölze. Bestimmung - Eigenschaften - Verwendung. Eugen Ulmer Verlag, Stuttgart.

SAS Institute Inc. (2003): SAS for Windows. 9.1 TS Level 1M2, SAS Institute Inc., Cary, NC, USA.

Schneider, S., D. Roessli and L. Excoffier (2000): Arlequin A software for population genetics data analysis. Version 2.000, http://cmpg.unibe.ch/software/arlequin3/

Taberlet, P., L. Gielley, G. Pautou and J. Bouvet (1991): Universal primers for amplification of three non-coding regions of chloroplast DNA. Plant Molecular Biology 17: 1105-1109.

Wissemann, V., H. Baumbach, S. MÜller, Y. Venus and F. H. HELLWIG (2007): Small scale analysis of population structure in Cornus mas L. by AFLP accentuates the need for a population based conservation strategy. Journal of Applied Botany 81: 175-177.

ZHukovsky, P. M. (1965): Main gene centres of cultivated plants and their wild relatives within the territory of the U.S.S.R. Euphytica 14: 177-188. 